\title{
BMJ Global Health WHO needs reform: why and how Syria was elected to the WHO Executive Board?
}

\author{
Tayseer AlKarim, ${ }^{1,2}$ Lia Harris, ${ }^{3}$ Abdullah Chahin ${ }^{4}$
}

To cite: AlKarim T, Harris $L$, Chahin A. WHO needs reform: why and how Syria was elected to the WHO Executive Board?BMJ Global Health 2021;6:e006801. doi:10.1136/ bmjgh-2021-006801

Handling editor Seye Abimbola

Received 2 July 2021

Accepted 8 July 2021

Check for updates

(C) Author(s) (or their employer(s)) 2021. Re-use permitted under CC BY-NC. No commercial re-use. See rights and permissions. Published by BMJ.

${ }^{1}$ Center for International Cooperation, New York University, New York, New York, USA

${ }^{2}$ The Center for Human Rights and Humanitarian Studies, Brown University Watson Institute for International Studies, Providence, Rhode Island, USA

${ }^{3}$ Pediatrics, The University of British Columbia Faculty of Medicine, Vancouver, British Columbia, Canada

${ }^{4}$ Infectious Diseases, Warren Alpert Medical School of Brown University, Providence, Rhode Island, USA

Correspondence to

Dr Lia Harris; liaharris@shaw.ca

\section{INTRODUCTION: WHO'S HISTORY AND RECORD}

WHO is the global leader in international public health with roles which include detecting and responding to acute health emergencies, ensuring preparedness for emergencies by identifying, mitigating and managing risks, supporting the development of tools essential for outbreaks, and supporting the delivery of essential health services in fragile settings. WHO works with its 194 Member States, across six regions, and from more than 150 offices with headquarters in Geneva. ${ }^{1}$ Governance takes place through the World Health Assembly, which is the supreme decision-making body; and the Executive Board, which gives effect to the decisions and policies of the Health Assembly. The Organisation is headed by the DirectorGeneral, who is appointed by the Health Assembly on the nomination of the Executive Board. This Board consists of 34 technically qualified members elected for 3-year terms. The main functions of the Board are to enact the decisions and policies of the Health Assembly, to advise it, and generally to facilitate its work. ${ }^{2}$

Given the prominence of the Executive Board to the workings of WHO and its influence on health internationally, Syria's election to the WHO Executive Board is, arguably a threat to everything WHO represents. ${ }^{3}$ Over the past 10 years, there have been more than 600 attacks on healthcare facilities and personnel in Syria, resulting in the killing of more than 930 medical professionals; more than $90 \%$ of such brutal attacks and deaths are attributed to Syrian government forces and their allies, according to Physicians for Human Rights. ${ }^{4}$ What is even harder to fathom, the representative of Assad's regime to the executive board is the Minister of Health, Dr Hassan Mohammad Al Ghabbash, who is on the list of both European Union (EU) and UK sanctions for 'sharing responsibility

\section{Summary box}

- Intergovernmental bodies, particularly the WHO have faced extraordinary global crises in recent decades.

- Their role in responding to the conflicts, violence, migration and internal displacement, disease outbreaks and the daunting challenge of climate change cannot be underestimated.

- Recent challenges faced by WHO arise from its internal constitution, which accepts an equitable geographical distribution in the Executive Board election but disregards the infamous human rights record of some elected members, particularly those involved in protracted conflicts or possibly engaged in war crimes.

- Another impediment to fair provision of global healthcare, is WHO donor funding is earmarked by donors, and not necessarily based on priority or needs.

- Urgent and decisive actions must be taken to avoid unparalleled consequences on the symbolic role of this intergovernmental agency.

- Increased accountability on WHO Executive Board elections, spending and practices, sustainable, condition-free funding and affected-communitycentred focus are essential for WHO to continue to ensure the organisation's integrity and reputation in the provision of healthcare to the world.

for the Syrian regime's violent repression against the civilian population'. ${ }^{56}$ This sanctioned representative 'shall enjoy immunity from every form of legal process' according to the WHO's Constitution. ${ }^{7}$ Belarus, another controversial admission to the Executive Board, has also been elected this year and though it is governed by a nominal democracy, it is essentially a dictatorship whose recent elections were deemed illegitimate by the international community. ${ }^{8}$ Such admissions to the Executive Board not only give an umbrella for human rights violators, but even more importantly, risk affecting processes in setting and applying policies, norms and standards of the WHO. 


\section{Thread}

WHO Syria $\bullet$

@WHOSyria

Today \#Syria was elected as a new member of the@WHO Executive Board (EB) among other newly joining members for the period of 3 years.

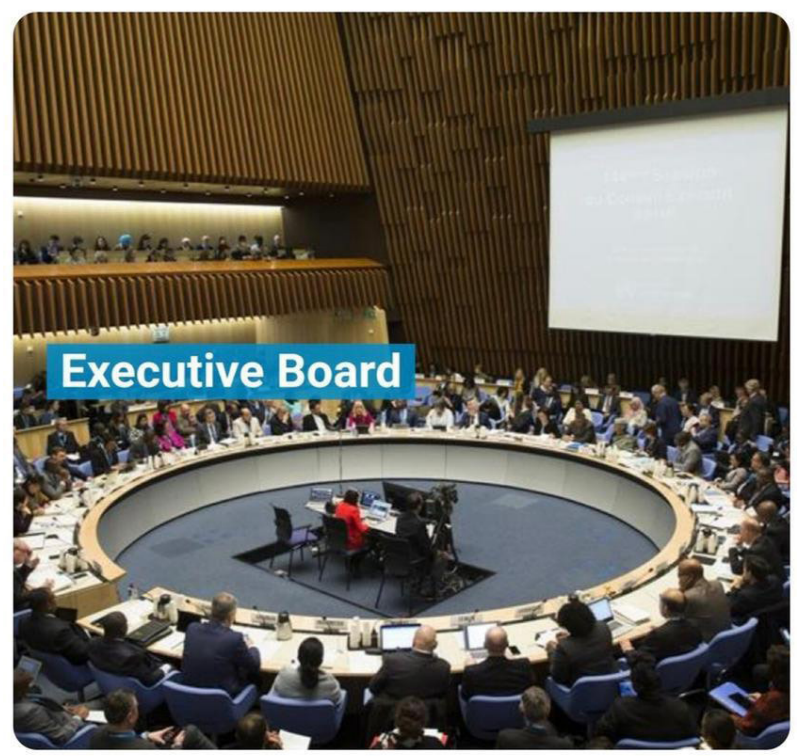

14:37 · 28/05/2021 - Twitter for Android

137 Retweets 740 Quote Tweets 237 Likes

Figure $1 \mathrm{WHO}$ announces the election of Syria to the WHO Executive Board.

For many both in and out of Syria, the election of Assad's regime is but another failure of the international community to stand with the millions of Syrians who have fallen victim to the regime. It will have both immediate effects on health and healthcare workers but may also affect recovery in Syria.

Therefore, the outrage of 'why Assad's regime has been elected?' must be redirected to answer, 'how has Assad's regime been elected?' as the answer will shape WHO's future and will either contribute to reasserting its leadership on the global health scene or contribute to accelerating its collapse.

\section{WHO'S MANDATE TO WORK WITHIN THE GOVERNMENTAL FRAMEWORK}

A fundamental challenge with WHO stems from its mandate to work only within the governmental framework; this poses problems where the government or sovereign state does not act in the best interests of its populations as seen in protracted conflict. The Assad government in Damascus is still the primary-and sometimes the only-recipient of the WHO's medical aid, yet the Organisation's own agencies confirm its deliberate targeting of hospitals, medical facilities and healthcare workers, as well as blockading areas and preventing the arrival of medicines, vaccines and food to civilians for consecutive years. ${ }^{9}$ Eastern Ghouta, an area of rural Damascus which was besieged by the Assad's forces between April 2013 and April 2018 was described as the longest running siege in modern history by the United Nations Commission of inquiry on Syria. ${ }^{10}$

The rise of authoritarian governments, coupled with the dynamics of modern armed conflicts which have severely fragmented the central governments, impose critical questions about the validity of WHO's operations through these governments. For too long, the WHO has failed to modernise its mandate of only working within the governmental framework, particularly in complex settings. Syria, as well as, Yemen provide important examples of the inadequacy of this mandate which can adversely affect the health of millions who fall outside of areas served by the sovereign state in these countries.

Though Assad still holds power in Damascus, his autocratic regime has been severely fragmented during the course of more than a decade of conflict. There are at least four areas of geopolitical control with Assad holding around two-thirds of the country, areas in the north east under Syrian Democratic Forces (SDF) control, areas in the northwest under opposition control and areas in the north under Turkish control. ${ }^{11}$

In Yemen, the fate of Ali Abdullah Saleh differed from Assad's; however, the country is no less divided after Saleh was ousted as president in 2012 then killed in 2017. The Yemeni territories are currently controlled by three regimes: the internationally recognised government, the Houthi movement and the Southern Transitional Council. ${ }^{12}$ In both countries, the emerging de facto authorities, acting as government in many regions, enjoy strong diplomatic and military backup from regional and international powers, but are not fully or equally recognised by the international community. However, WHO has paradoxically interpreted its mandate in these countries. In Yemen, WHO is running its operations from Sana'a, under the internationally unrecognised Houthi movement, while in Syria, it is operating from Damascus, under Assad's regime. As a result, millions of Syrian and Yemeni civilians are left under the mercy of their perpetrators.

\section{WHO IS MANAGING GLOBAL HEALTH CRISES?}

There is a unique opportunity to improve with every crisis, and so the governance and operational crises facing the $\mathrm{WHO}$, and more broadly other intergovernmental organisations, provide a crucial chance for progress.

Several reports have called out the WHO for delaying the announcement of COVID-19 as a global pandemic 
and neglecting the pandemic in China for political reasons, while praising the country's leadership for its 'openness to sharing information' and calling on nations not to limit travel to China. ${ }^{13}$ On 14 January 2020, the WHO had sent out a tweet repeating the Chinese authorities' rhetoric that there is no evidence of human-tohuman transmission. The resulting delay in responding to the emergence of the novel coronavirus undoubtedly contributed to the unprecedented scale of the outbreak globally. The WHO was also very late in declaring the outbreak a pandemic. The controversies around the role and performance of the WHO in this pandemic are many, and they—sadly-are a continuation of a longer legacy.

Previously, in 2009-2010 the WHO conceded shortcomings in its handling of the H1N1 pandemic, including a failure to communicate uncertainties about the new virus as it swept across the globe. ${ }^{14}$ Similarly, in 2013-2016 during the Ebola outbreak, the WHO was unable to provide an effective operational response with concerns that epidemiologists who were sent to West Africa had only scant knowledge of Ebola and weak WHO protocols for disease outbreak management. ${ }^{15}$

At a local level, during the Ebola outbreak, WHO employees in Democratic Republic of Congo were accused of sexual exploitation and violence, in exchange for employment with WHO, the details of which were believed to be known by executive in the WHO at the time. ${ }^{16}{ }^{17}$ Another unearthed disgrace was the travel costs scandal, where internal documents revealed that WHO has routinely spent about $\$ 200$ million a year on travel expenses, more than what it spends on tackling AIDS, tuberculosis and malaria combined. ${ }^{18}$

\section{CONCLUSION: CORNERSTONES TO SAFEGUARDING WHO'S SYMBOLISM AND LEGACY \\ Accountability}

While an independent international body capable of responding to widespread health crises is essential in this time of globalisation, WHO is required more than ever to protect its legacy from the influence of governments who violate human rights. The sanctioned delivery of financial and material support to dictatorships which systematically destroy the health sector in their countries must be critically examined by academics or objective outsiders.

\section{Sustainable, condition-free funding}

One weakness of the governance of the WHO, lies in its funding source, primarily Member States assessed and voluntary contributions. As anyone who has worked within non-governmental organisations knows, the operations are donor-driven. With $80 \%$ of donated WHO funds being earmarked for specific projects even if they are not a priority for the affected communities, individual countries will continue to impact WHO agenda, until alternate objective flexible funding is available. ${ }^{19}$ Ensuring guaranteed, contingency-free funding, and accountable accounting is essential in shaping the organisation's future and contributing to asserting its leadership in global health.

\section{Affected-community-centred approach}

Empowering the voice of crisis-affected populations is possibly the most critical concept for the provision of optimum healthcare in the 21st century. Disadvantaged groups must all be involved in creating a better future for themselves and their communities, especially those debilitated by violent conflicts, debts, poverty, drought and epidemics. WHO's vital role must be protected from members who have violated these basic human rights.

The appointment of Assad's regime could be hard to reverse from a technical point of view, but from humanitarian and human rights perspectives, reversing the appointment and ensuring governments with similar records do not gain executive positions, are essential steps in alleviating the despair and distrust of the millions of vulnerable not only in Syria but across the globe. Further manifestations of distrust in WHO will negatively impact resilience and increase fragility and vulnerability in the humanitarian crisis zones. The privilege of autocratic members in influencing WHO's Executive Board undoubtedly risks its global efforts to fulfil its aim 'to promote health, keep the world safe, and serve the vulnerable'. ${ }^{20}$

Twitter Tayseer AlKarim @TayseerAlkarim, Lia Harris @HarrisLiaharris and Abdullah Chahin @abdullah.chahin

Acknowledgements Appreciation to Dr Aula Abbara for previewing and providing feedback on the manuscript.

Contributors TA conceived the idea and worked with $A C$ to produce the first draft. $\mathrm{TA}, \mathrm{AC}$ and $\mathrm{LH}$ edited the manuscript.

Funding The authors have not declared a specific grant for this research from any funding agency in the public, commercial or not-for-profit sectors.

Competing interests None declared.

Patient consent for publication Not required.

Provenance and peer review Not commissioned; internally peer reviewed.

Data availability statement Data are available in a public, open access repository.

Open access This is an open access article distributed in accordance with the Creative Commons Attribution Non Commercial (CC BY-NC 4.0) license, which permits others to distribute, remix, adapt, build upon this work non-commercially, and license their derivative works on different terms, provided the original work is properly cited, appropriate credit is given, any changes made indicated, and the use is non-commercial. See: http://creativecommons.org/licenses/by-nc/4.0/.

\section{REFERENCES}

1 Who we are [Internet]. Who.int, 2021. Available: https://www.who.int/ about/who-we-are

2 WHO. Governance, 2014. Available: https://web.archive.org/web/ 20140213212358/http:/www.who.int/governance/en/index.html

3 unwatch. Syria elected to WHO executive board, activists outraged [Internet]. Unwatch.org, 2021. Available: https://unwatch.org/syriaelected-to-who-executive-board-activists-outraged/

4 Medical personnel are targeted in Syria - physicians for human rights [Internet]. Phr.org, 2019. Available: https://phr.org/our-work/ resources/medical-personnel-are-targeted-in-syria/

5 Europa.eu, 2021. Available: https://eur-lex.europa.eu/legal-content/ EN/TXT/PDF/?uri=CELEX:32020R1649\&rid $=4$

6 Status: Asset Freeze Targets. Consolidated list of financial sanctions targets in the UK [Internet]. Gov.uk, 2021. Available: https://assets. 
publishing.service.gov.uk/government/uploads/system/uploads/ attachment_data/file/973238/Syria.pdf

7 Basic documents. ED. 49. Who.int, 2021. Available: https://apps. who.int/gb/bd/pdf files/BD 49th-en.pdf\#page=213

8 Taylor A. Photos: Anger and protest over a presidential election in Belarus. Atlantic monthly (Boston, Mass: 1993) [Internet], 2020. Available: https://www.theatlantic.com/photo/2020/08/photosanger-and-protest-over-presidential-election-belarus/615451/

9 Deadly attacks on civilians in Syria's idlib region 'happening in plain sight, under our watch', under-secretary-general tells security council [Internet]. Www.un.org, 2021. Available: https://www.un.org/ press/en/2020/sc14132.doc.htm

$10 \mathrm{OHCHR}$ [Internet]. Ohchr.org, 2021. Available: https://www.ohchr. org/en/NewsEvents/Pages/DisplayNews.aspx?NewsID=23226

11 Woodward M. COVID-19 exposes weaknesses in Syria's fragmented and war-torn health system [Internet]. Merip.org, 2020. Available: https://merip.org/2020/12/covid-19-exposes-weaknesses-in-syriasfragmented-and-war-torn-health-system/

12 AlKarim T, Abbara A, Attal B. Armed conflict alone does not explain the devastation of Yemen's health system. BMJ Glob Health 2021;6:e004740.

13 WHO decision on $\mathrm{nCoV}$ emergency delayed as cases spike [Internet]. Umn.edu, 2021. Available: https://www.cidrap.umn.edu/ news-perspective/2020/01/who-decision-ncov-emergency-delayedcases-spike
$14 \mathrm{WHO}$ admits shortcomings in handling flu pandemic. Reuters [Internet], 2010. Available: https://www.reuters.com/article/us-whoidUSTRE63B2TL20100412

15 Wenham $\mathrm{C}$. What we have learnt about the world Health organization from the Ebola outbreak. Philos Trans $R$ Soc Lond B Biol Sci 2017;372. doi:10.1098/rstb.2016.0307. [Epub ahead of print: 26 May 2017].

16 Flummerfelt R, Kasongo A. New sex abuse claims against aid workers in Congo [Internet]. Thenewhumanitarian.org, 2021. Available: https://www.thenewhumanitarian.org/2021/05/12/ exclusive-new-sex-abuse-claims-against-ebola-aid-workersexposed-congo

17 Cheng M. Internal emails reveal WHO knew of sex abuse claims in Congo [Internet]. Associated Press, 2021. Available: https://apnews.com/article/united-nations-europe-ebola-virusentertainment-coronavirus-pandemic-d14715ba3653753d7c1f122f 8aea79de

18 Cheng M. AP Exclusive: Health agency spends more on travel than AIDS [Internet]. Associated Press, 2017. Available: https://apnews. com/article/1cf4791dc5c14b9299e0f532c75f63b2

19 How WHO is funded [Internet]. Who.int, 2021. Available: https:// www.who.int/about/funding

20 What we do [Internet]. Who.int, 2021. Available: https://www.who. int/about/what-we-do 